\title{
Immunochemistry of the cell surfaces of Bacteroides bivius and Bacteroides disiens
}

\author{
R. BROWN, KAREN E. HORNETT and I. R. POXTON*
}

\section{Department of Bacteriology, University of Edinburgh Medical School, Teviot Place, Edinburgh EH8 9AG}

\begin{abstract}
Summary. Outer membranes were extracted from seven strains of Bacteroides bivius and six strains of $B$. disiens by the Sarkosyl method. Lipopolysaccharides (LPS) were extracted from the same strains by the Proteinase K method, and from three strains of each species by an aqueous phenol method. Analysis of the outer-membrane proteins by SDS-PAGE demonstrated that, within a species, very similar patterns with many shared or common bands were produced, but there were sufficient differences between species to allow separation. Immunoblotting with antisera raised against whole cells of each of the type strains showed that many antigens were shared between species. Smooth LPS was present in both species. By immunoblotting, the O-antigen of $B$. disiens was shown to be common to all six strains, and there was no cross-reaction between the $B$. disiens antiserum and $B$. bivius LPS. The O-antigen of $B$. bivius was not detected by immunoblotting with homologous antiserum, but antiserum to $B$. bivius reacted with a series of common low molecular mass antigens that were present in LPS preparations from strains of both species.
\end{abstract}

\section{Introduction}

Bacteroides bivius and $B$. disiens are closely related species of anaerobic, gram-negative bacteria that share the same main ecological niche, being most commonly isolated from the vagina and cervix in both health and disease and from genital infections in the male (Holdeman and Johnson, 1977; Duerden, 1980). Both species are non-pigmented, bile sensitive, weakly saccharolytic and proteolytic, and do not produce indole. They are differentiated by the ability of most $B$. bivius strains to produce acid from lactose and galactose whereas no strains of $B$. disiens ferment either of these sugars. DNA hybridisation has shown that they are distinct species (Holdeman et al., 1977; Holdeman and Johnson, 1977).

Sodium dodecyl sulphate-polyacrylamide gel electrophoresis (SDS-PAGE) of cell-surface proteins has been a useful aid in the identification of species and sub-types of a range of bacteria, including anaerobes (Poxton and Brown, 1979; Moore et al., 1980). The aim of the present study was to use SDS-PAGE in conjunction with immunoblotting to compare the outer-membrane proteins and lipopolysaccharide (LPS) of several strains of $B$. bivius and $B$. disiens to determine any inter- or

Received 20 Sept. 1988; accepted 26 Oct. 1988.

* Correspondence should be sent to Dr I. R. Poxton. intra-species similarities or differences. The Sarkosyl method for the preparation of outer-membrane proteins and the Proteinase K method for LPS were chosen for their simplicity and applicability to small culture volumes; these advantages make the methods particularly useful for diagnostic or taxonomic investigations. LPS extracted by the Proteinase $\mathrm{K}$ method was compared with that extracted by the classical aqueous phenol method.

\section{Materials and methods}

\section{Bacterial strains}

B. bivius strains VPI 6822 and VPI 6318, and $B$. disiens strains VPI 8057 and VPI 7582 were obtained from the Virginia Polytechnic Institute and State University, Blacksburg, VA, USA. Strain GNAB 12 was isolated from a high vaginal swab in this department. The MW series of strains was supplied by Dr B. Watt, City Hospital, Edinburgh. Identity of strains was confirmed by the method of Brown et al. (1989). Tests included bile tolerance, indole production, fermentation of glucose, lactose, sucrose and maltose, and gelatinase activity.

\section{Preparation of outer membrane}

Cultures were prepared by seeding $500-\mathrm{ml}$ volumes of pre-reduced proteose peptone-yeast extract (PPY) broth (Deacon et al., 1978) with $25 \mathrm{ml}$ of 48 -h starter cultures 
in the same medium. They were incubated anaerobically $\left(\mathrm{H}_{2} 90 \%, \mathrm{CO}_{2} 10 \%\right)$ for $24 \mathrm{~h}$ at $37^{\circ} \mathrm{C}$. The cells were harvested and washed once in $200 \mathrm{ml}$ of phosphatebuffered saline ( $50 \mathrm{~mm}$ phosphate buffer, $\mathrm{pH} 7 \cdot 4$, containing $0.15 \mathrm{M} \mathrm{NaCl}$; PBS). The centrifuge tubes were drained and the pellet was suspended in $5 \mathrm{ml}$ of distilled water. The cells were broken by passage through a French pressure cell (Aminco, Silver Springs, MD, USA) at $6000 \mathrm{psi}(42 \mathrm{MPa})$ at $0^{\circ} \mathrm{C}$. Unbroken cells were removed by centrifugation at $6000 \mathrm{~g}$ for $10 \mathrm{~min}$ at $4^{\circ} \mathrm{C}$. A modification of the method of Filip et al. (1973) was used for Sarkosyl treatment. One volume of a $7 \% \mathrm{w} / \mathrm{v}$ solution of sodium $\mathrm{N}$-lauroyl sarcosinate was added to nine volumes of the broken-cell suspension. The insoluble outer membrane was harvested and washed once in $5 \mathrm{ml}$ of distilled water by centrifugation at $50000 \mathrm{~g}$ at $4^{\circ} \mathrm{C}$ for $1 \mathrm{~h}$. The pellet was resuspended in $0.5 \mathrm{ml}$ of distilled water by repeated aspiration into a syringe through a 26gauge needle. The suspension was stored at $-20^{\circ} \mathrm{C}$. Protein was assayed by the method of Lowry et al. (1951).

\section{Preparation of LPS}

The Proteinase $\mathrm{K}$ method for LPS extraction was modified from Hitchcock and Brown (1983). Volumes $(5 \mathrm{ml})$ of the cultures prepared for Sarkosyl extraction were harvested and washed twice in PBS by centrifugation at $4000 \mathrm{~g}$ at $4^{\circ} \mathrm{C}$ for $15 \mathrm{~min}$. The pellet was suspended in PBS to an $A_{525}$ of 0.6 and $1.5-\mathrm{ml}$ volumes were centrifuged at approximately $10000 \mathrm{~g}$ for $90 \mathrm{~s}$ (Microfuge Beckman Model B). The pellet was solubilised in $50 \mu \mathrm{l}$ of PAGE sample buffer $(0.0625 \mathrm{M}$ Tris- $\mathrm{HCl}, \mathrm{pH} 6.8$, containing sodium dodecyl sulphate $2 \% \mathrm{w} / \mathrm{v}$, glycerol $10 \% \mathrm{v} / \mathrm{v}, 2$-mercaptoethanol $1 \% \mathrm{v} / \mathrm{v}$ and bromophenol blue $0.001 \% \mathrm{w} / \mathrm{v}$ ) and heated in a boiling water-bath for $10 \mathrm{~min}$. Proteinase $\mathrm{K}(25 \mu \mathrm{g})$ (Sigma Protease XI) in $10 \mu \mathrm{l}$ of sample buffer was added to each tube and then incubated at $60^{\circ} \mathrm{C}$ for $1 \mathrm{~h}$. Samples were stored at $-20^{\circ} \mathrm{C}$.

The aqueous phenol method for the extraction of LPS was that of Poxton and Brown (1986).

Carbohydrate was assayed by the method of Dubois $e t$ al. (1956).

\section{$S D S-P A G E$}

SDS-PAGE was performed on $10 \%$ slab gels with the Laemmli buffer system (Laemmli, 1970) by the method of Poxton and Brown (1979). Samples $(25 \mu \mathrm{l}$ or $100 \mu \mathrm{l})$ of the Proteinase K LPS extracts, 50- $\mu$ l or 100- $\mu$ l samples of the aqueous phenol extracts containing $10 \mu \mathrm{g}$ or $20 \mu \mathrm{g}$ of carbohydrate respectively, or $50-\mu \mathrm{l}$ samples containing 9-25 $\mu \mathrm{g}$ of protein of the Sarkosyl preparations were loaded on to the gels. The LPS separating gels were stained by a modification of the silver stain methods of Tsai and Frasch (1982) and Hitchcock and Brown (1983). The gel was fixed in $200 \mathrm{ml}$ of propan-2-ol $25 \% \mathrm{v} / \mathrm{v}$, acetic acid $7 \% \mathrm{v} / \mathrm{v}$ overnight, and then oxidised in freshly prepared periodic acid $1.05 \mathrm{~g}$ in $150 \mathrm{ml}$ of distilled water containing $4 \mathrm{ml}$ of the above fixative for $5 \mathrm{~min}$. The gel was then washed in at least four changes of $200 \mathrm{ml}$ of distilled water over $4 \mathrm{~h}$, drained and added to fresh ammoniacal silver nitrate solution $-1.4 \mathrm{ml}$ of ammonia solution (SG 0.88 ) was added to $21 \mathrm{ml}$ of $\mathrm{NaOH} 0.36 \%$, and $4 \mathrm{ml}$ of $\mathrm{AgNO}_{3}, 19.4 \%$ solution was added with vigorous agitation; after the brown precipitate had disappeared, the volume was made up to $100 \mathrm{ml}$ with distilled water. After $15 \mathrm{~min}$, the gel was washed in at least four changes of distilled water over $40 \mathrm{~min}$ and then transferred to a fresh solution of citric acid $0.005 \%$ in $200 \mathrm{ml}$ of formaldehyde $0.019 \%$ at $25^{\circ} \mathrm{C}$. When the desired staining intensity was reached, the gel was washed repeatedly in large volumes of distilled water.

The Sarkosyl outer-membrane gels were stained with Coomassie blue by the method of Poxton and Sutherland (1976).

\section{Immunoblot transfer}

This was based on the method of Towbin et al. (1979) as described by Cousland and Poxton (1983) with BioRad immunoblotting reagents, but the nitrocellulose membrane was of $0 \cdot 2-\mu \mathrm{m}$ pore size (Sartorius). For dot blotting, $2 \mu \mathrm{l}$ of aqueous phenol-extracted LPS was applied directly to the nitrocellulose. Antisera were used at a dilution of 1 in 100 .

\section{Preparation of antisera}

Antisera were raised in rabbits against washed whole cells of the type strains-B. bivius VPI 6822 and $B$. disiens VPI 8057 - and against $B$. bivius VPI 6318 by the method of Poxton et al. (1982).

Samples of the antisera raised against the type cultures were absorbed with their homologous aqueous phenolextracted LPS. Serum $(2 \mathrm{ml})$ was mixed with $1 \mathrm{ml}$ of a solution containing $1 \mathrm{mg}$ of LPS $(0.2 \mathrm{ml}$ of an aqueous solution of LPS $5 \mathrm{mg} / \mathrm{ml} \mathrm{w} / \mathrm{v}+0.8 \mathrm{ml}$ of PBS) and agitated on a blood-cell mixer at $15^{\circ} \mathrm{C}$ for $1.5 \mathrm{~h}$. After centrifugation at $10000 \mathrm{~g}$ at $15^{\circ} \mathrm{C}$ for $5 \mathrm{~min}$, the supernate was reextracted as above. Unreacted LPS and immune complexes were removed by two cycles of centrifugation at $100000 \mathrm{~g}$ at $4^{\circ} \mathrm{C}$ for $3 \mathrm{~h}$, and the supernate was collected and stored at $-20^{\circ} \mathrm{C}$. The absorbed sera were shown by dot blotting not to react at a final dilution of 1 in 100 with their homologous aqueous phenol LPS.

\section{Results}

\section{SDS-PAGE and immunoblotting of Sarkosyl outer- membrane preparations}

Fig. 1 shows examples of the patterns obtained after separation and Coomassie-blue staining of Sarkosyl extracts of seven strains of $B$. bivius and six of $B$. disiens. The patterns produced by the $B$. 


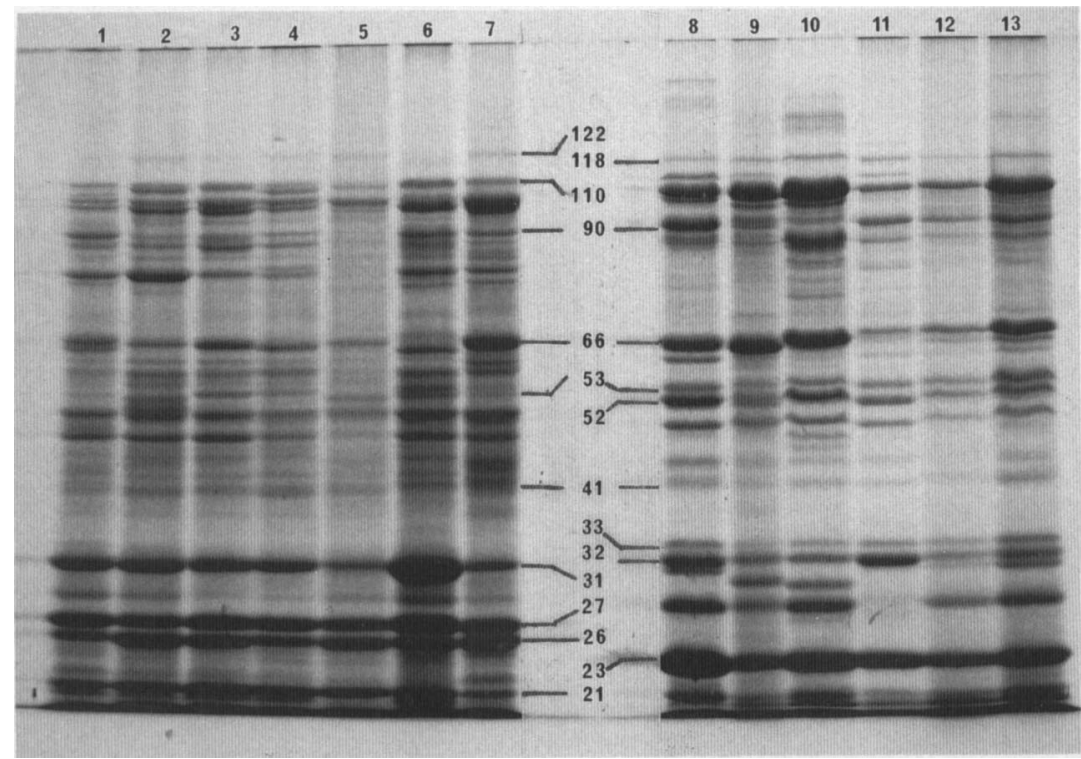

Fig. 1. SDS-PAGE of Sarkosyl outer-membrane preparations of B. bivius and B. disiens strains separated on acrylamide $10 \%$ slab gels stained with Coomassie blue. Track 1, B. bivius VPI 6822; 2, MW 1; 3, MW 3; 4, MW 6; 5, MW 8; 6, MW 15; 7, VPI 6318; 8, B. disiens VPI 8057; 9, MW 20; 10, VPI 7582; 11, GNAB 12; 12, MW 19; 13, MW 21. Molecular masses are in Kda.

bivius strains (tracks $1-7$ ) show much similarity to one another with many shared or common bands and only a few strain-specific bands, and have in particular four major common bands of approximately $31,27,26$ and $21 \mathrm{Kda}$. The patterns produced by the six $B$. disiens strains (tracks 8-13) show less similarity to each other with more strainspecific bands but still have a great many shared or common bands. One major common band of $23 \mathrm{Kda}$, and a common duplex of $32-33 \mathrm{Kda}$ are seen. Several bands appeared to be shared by both species, and bands of approximately $90,66,53$ and $41 \mathrm{Kda}$ appear to be common to all strains of both species.

Three gels identical to those shown in fig. 1 were run and each was transferred to nitrocellulose membranes. One of these blots was probed with antiserum raised against whole cells of $B$. bivius VPI 6822 (fig. 2a) and the second was probed with antiserum to $B$. disiens VPI 8057 (fig. 2b). The third blot was cut to separate the two species and each was probed with its homologous antiserum which had been absorbed with its own LPS. Fig. 2a shows that all the $B$. bivius strains (tracks $1-7$ ) have almost identical profiles except for slight quantitative differences and a few strain-specific antigens. There are many common antigens and the general profile bears some resemblance to the pattern in fig. 1, all the major protein bands being antigenic. A greatly elongated high-molecular-mass band partially obscuring the separated protein bands and clearly seen in the upper half of the homologous reaction (track 1) and faintly in track 2 were also seen in immunoblots of Proteinase $\mathrm{K}$ extracts of the same two strains (see fig. 4a later). Curved bands seen clearly at the front of tracks 1,3 and 6 , and less clearly in tracks $2,4,5$ and 7 , were not seen in the Coomassie blue-stained gel. When these seven Sarkosyl preparations were probed with LPSabsorbed $B$. bivius antiserum, the latter two described bands were not seen, indicating that they were LPS antigens. Antigens of 53, 46 and $29 \mathrm{Kda}$ were also not detected with the absorbed serum.

The heterologous reactions in tracks 8-13 show that there are a considerable number of $B$. disiens antigens that cross-react with $B$. bivius antiserum. Again, some of these antigens correspond to the $B$. disiens outer-membrane-protein bands in fig. 1. A few of the bands $(122,72$ and $27 \mathrm{Kda})$ appear to be common to $B$. bivius and $B$. disiens but three of the four major common protein antigens of $B$. bivius appear to be species specific. The $23-$ and $33-\mathrm{Kda}$ common protein bands were detected by the $B$. bivius antiserum.

Fig. $2 b$ shows the same strains as in fig. 1, probed with the antiserum raised against $B$. disiens VPI 8057. The six $B$. disiens strains (tracks 8-13) share common antigens of $122,118,72,52$ and $33 \mathrm{Kda}$. 

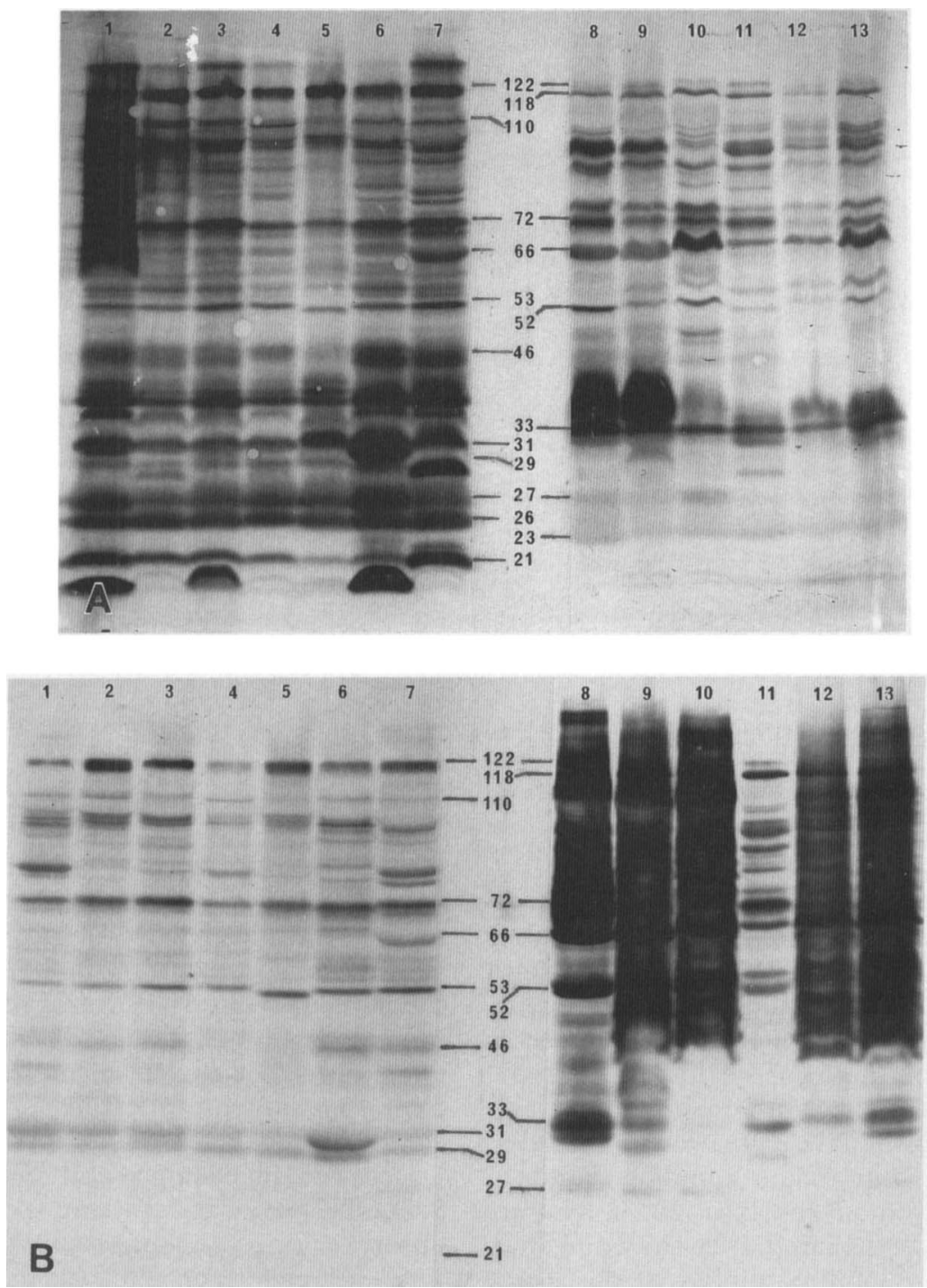

Fig. 2. Immunoblot of Sarkosyl outer-membrane preparations of $B$. bivius and $B$. disiens after separation as in fig. 1 and transfer to nitrocellulose membrane. Tracks were loaded with the same samples as in fig. 1 . Gels were probed with (a) B. bivius VPI 6822 and (b) with $B$. disiens VPI 8057 whole cell antisera, followed by anti-rabbit IgG-horseradish peroxidase conjugate and colour development. Molecular masses are in Kda.

Several antigenic bands, seen most clearly in track 11 , of 118,52 and $33 \mathrm{Kda}$ correspond to the protein bands in fig. 1. In the upper half of the other tracks, several extra bands, not revealed by the Coomassie blue-stained gel, have largely obscured the protein bands. These are shown to be LPS antigens below. When these six Sarkosyl preparations were probed with LPS-absorbed $B$. disiens antiserum, all tracks, with the exception of a few strain-specific bands, were identical to each other and to the pattern produced by strain GNAB 12 (track 11) in fig. 2 b.
Some of the low-molecular-mass protein bands, including the major $23-\mathrm{Kda}$ common protein, are not apparently antigenic.

The heterologous reactions (tracks 1-7) again reveal a considerable number of cross-reacting antigens that are identical to the corresponding tracks in fig. 2a. However, in fig. 2b many of the bands in the lower half of the gel are either absent or gave very weak reactions. The elongated highmolecular-mass band seen in tracks 1 and 2 in fig. $2 \mathrm{a}$ were absent in fig. $2 \mathrm{~b}$. 


\section{SDS-PAGE and immunoblotting of aqueous phenol and Proteinase K LPS extracts}

Fig. 3 shows examples of patterns obtained after separation and silver staining of aqueous phenol extracts of three strains of $B$. bivius and two of $B$. disiens. With the exception of B. bivius strain MW8 (track 3) even when overloaded, smooth LPS ladder patterns, resembling those found in some Enterobacteriaceae, were seen. A considerable amount of material was seen at the front of all tracks. The $B$. bivius tracks had in common a series of four or so low-molecular-mass bands which may be a lowmolecular-mass ladder pattern, and an elongated high-molecular-mass band. The $B$. disiens tracks had two common bands in addition to the ladder pattern. The first was a high-molecular-mass dumbbell shaped band, and the other was a lowmolecular-mass band (both arrowed).

When $B$. bivius aqueous phenol extracts were probed with antisera raised against $B$. bivius strains VPI 6822 and VPI 6318, no smooth LPS ladder pattern was seen. All other bands seen in the silverstained gel were antigenic; at least three of the series of four low-molecular-mass bands were common antigens and the front material and elongated high-molecular-mass material appeared to be strain specific. Ladder patterns common to all three $B$. disiens aqueous phenol extracts were demonstrated when probed with antiserum raised against $\boldsymbol{B}$. disiens VPI 8057 (data not shown). These results are identical to those described below for Proteinase K extracted LPS (see fig. $4 \mathrm{a}$ and $\mathrm{b}$ ).

Proteinase $\mathrm{K}$ extracts of all strains belonging to both species were separated by SDS-PAGE, transferred to nitrocellulose and probed with homologous and heterologous antisera. With B. bivius VPI 6822 antiserum (fig. 4a), all seven extracts of $B$. bivius (tracks 1-7) showed reactions with the series of low-molecular-mass LPS antigens. An elongated high-molecular-mass band in tracks 1 and 2, and an antigen at the front in tracks 1,3 and 6 correspond to antigens seen in the immunoblot of the Sarkosyl extracts of the same strains probed with the same serum (fig. 2a). Marked crossreactions are seen with the series of low-molecularmass antigens from five of the six Proteinase $K$ extracts of $B$. disiens (tracks 8-13); strain GNAB 12 (track 11) showed no heterologous reaction. Faint high-molecular-mass smooth LPS ladder patterns are visible in tracks 8 and 10 (VPI 8057 and VPI 7582 respectively).

In the reaction between $B$. disiens Proteinase $\mathrm{K}$ extracts and homologous antiserum (fig. 4b), all six strains were seen to have a smooth LPS ladder pattern (tracks 8-13); the bands in track 11 (GNAB 12) were fainter and more widely spaced than in the other tracks. The low-molecular-mass bands that cross reacted strongly with the $B$. bivius antiserum have reacted only weakly with homolo-

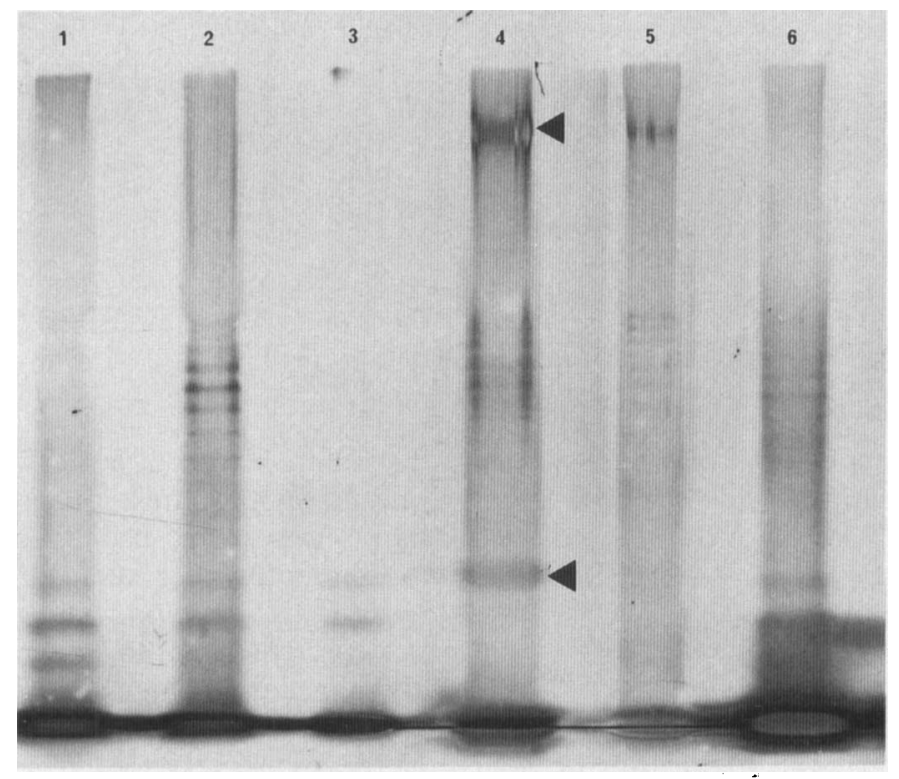

Fig. 3. SDS-PAGE of aqueous phenol extracts of $B$. bivius and $B$. disiens strains stained with silver. Tracks 1 and 6 , B. bivius VPI 6822 ; 2, VPI $6318 ; 3, \mathrm{MW} 8 ; 4, B$. disiens VPI 8057; 5, VPI 7582. Tracks $1-5$ were loaded with $10 \mu$ g of carbohydrate. Track 6 was loaded with $20 \mu \mathrm{g}$ to demonstrate ladder pattern. 

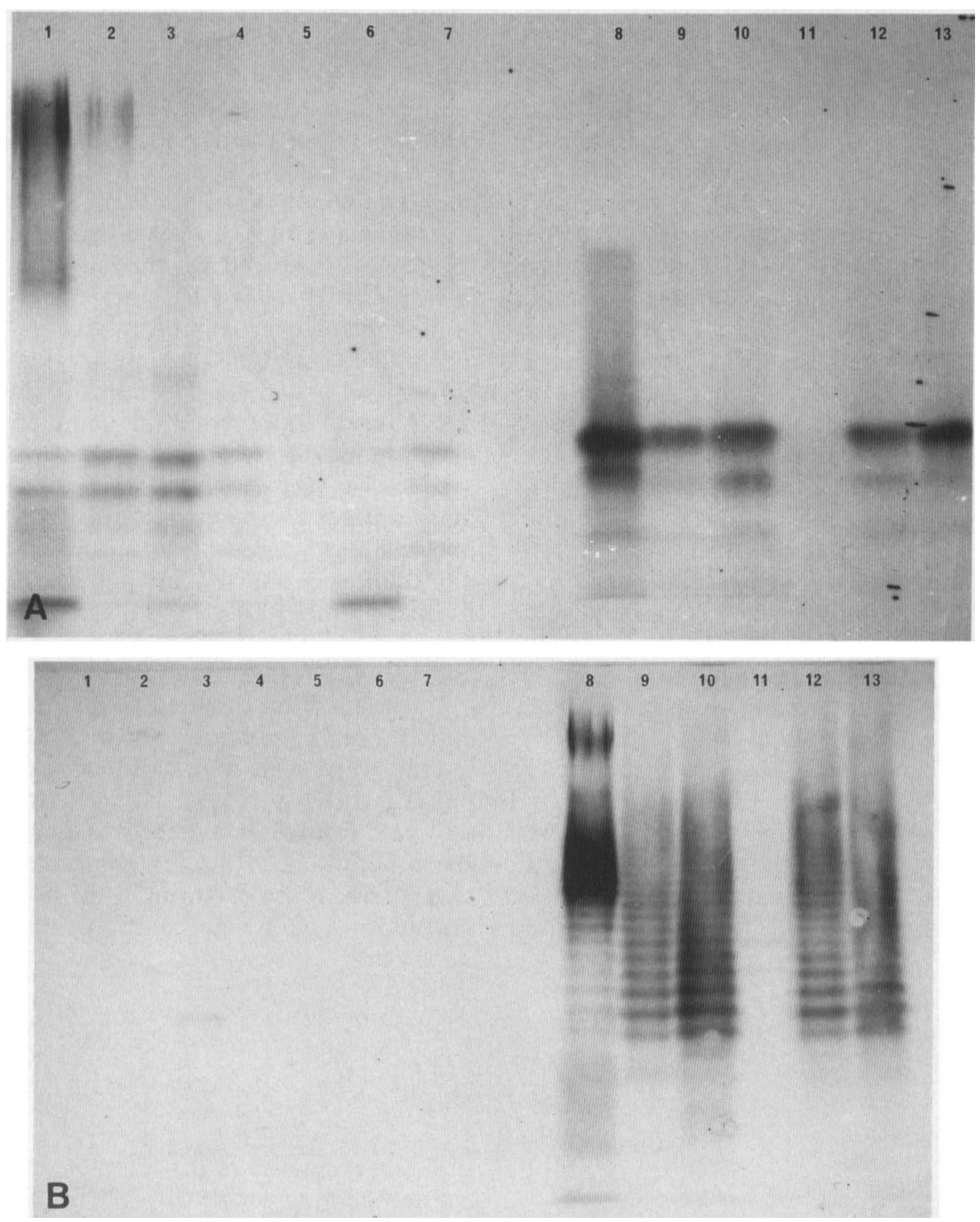

Fig. 4. Immunoblots of Proteinase $\mathrm{K}$ extracts of $B$. bivius and $B$. disiens strains, arranged as in fig. 1, probed with (a) B. bivius VPI 6822 and (b) B. disiens VPI 8057 whole cell antisera.

gous serum. A strain-specific dumb-bell-shaped antigen is seen near the top of track 8 . The $B$. bivius Proteinase $\mathrm{K}$ extracts have not cross-reacted with the $B$. disiens antiserum.

\section{Discussion}

The Sarkosyl method for the preparation of outer membranes, when applied to $B$. bivius and $B$. disiens, gives protein patterns on SDS-PAGE that are similar to those produced by most gram-negative bacteria. Many different bands of protein are visualised and there are a few strongly staining bands which are usually classified as the major outer-membrane proteins. The patterns produced by strains belonging to the same species are sufficiently similar to each other but different from other species to allow identification to species level. Gram-negative bacteria that are closely related have cross-reactive outer-membrane antigens (Hofstra and Dankert, 1980) and these two closely related Bacteroides spp. have several protein antigens in common. 
Immunoblotting of LPS with two $B$. bivius antisera detected a series of low-molecular-mass antigens that were common to that species and that also cross-reacted with a similar series of antigens of slightly different molecular mass in strains of $\boldsymbol{B}$. disiens. These $B$. bivius antisera reacted with their homologous high-molecular-mass antigens but no clear ladder pattern was revealed. They did however, react weakly with high-molecular-mass ladder patterns in two strains of $B$. disiens. Antiserum raised against the type strain of $B$. disiens detected smooth LPS ladder patterns in all strains of that species, but did not cross-react with $B$. bivius LPS.

The LPS of gram-negative bacteria, especially the $\mathrm{O}$ antigenic part, is usually considered to be highly variable within a species. The core, however, is often much more conserved and there are regions, especially in the inner core, that are common within a species and even among species. This may explain the shared series of low-molecular-mass LPS antigens of these two species which consist of LPS molecules with a relatively higher proportion of core oligosaccharide than $\mathrm{O}$ antigen repeating units. The B. bivius strains appear to have produced

\section{REFERENCES}

Brown R, Collee J G, Poxton I R, Fraser A G 1989 Bacteroides and related genera. In: Collee $J \mathrm{G}$ et al. (eds) Mackie and McCartney's Medical Microbiology, vol 2, 13th edn. Churchill Livingstone, Edinburgh.

Cousland G, Poxton I R 1983 Analysis of lipopolysaccharides of Bacteroides fragilis by sodium dodecyl sulphate-polyacrylamide gel electrophoresis and electroblot transfer. FEMS Microbiology Letters 20 : 461-465.

Deacon A G, Duerden B I, Holbrook W P 1978 Gas-liquid chromatographic analysis of metabolic products in the identification of Bacteroidaceae of clinical interest. Journal of Medical Microbiology 11 : 81-99.

Dubois M, Gilles K A, Hamilton J K, Rebers P A, Smith F 1956 Colorimetric method for determination of sugars and related substances. Analytical Chemistry 28: 350-356.

Duerden B I 1980 The isolation and identification of Bacteroides spp. from the normal human vaginal flora. Journal of Medical Microbiology 13: 79-87.

Filip C, Fletcher G, Wulff J L, Earhart C F 1973 Solubilization of the cytoplasmic membrane of Escherichia coli by the ionic detergent sodium-lauroyl sarcosinate. Journal of Bacteriology 115 : 717-722.

Hitchcock P J, Brown T M 1983 Morphological heterogeneity among Salmonella lipopolysaccharide chemotypes in silverstained polyacrylamide gels. Journal of Bacteriology 154 : 267-277.

Hofstra H, Dankert J 1980 Major outer membrane proteins: common antigens in Enterobacteriaceae species. Journal of General Microbiology 119: 123-131.

Holdeman L V, Cato E P, Moore W E C 1977 Anaerobic Laboratory Manual, 4th edn. Anaerobe Laboratory, Virginia Polytechnic Institute and State University, Blacksburg, VA. a strong anti-core antibody response, whereas the $B$. disiens has produced a strong anti-O response.

In summary, $B$. bivius and $B$. disiens are closely related in respect to outer-membrane proteins although differences permit species identification. The two species are related serologically (Poxton et $a l ., 1982$ ) and we have demonstrated in this study that cross-reactivity is due to shared outer-membrane proteins and low-molecular-mass LPS material, suggesting that they have common core structures. In this study, both species were shown to have smooth LPS; the typical O-antigen ladder pattern of $\boldsymbol{B}$. disiens reacted well with homologous antiserum and appeared to be common to all strains with the possible exception of GNAB 12. A highmolecular-mass ladder pattern of $B$. bivius was not detected by immunoblotting but a strain-specific high-molecular-mass antigen, not resolved into a ladder pattern, was observed.

We are grateful to Professor J. G. Collee for his interest and help in the preparation of the manuscript. K. E. H. was the holder of an intercalated award from the Medical Research Council.

Holdeman L V, Johnson J L 1977 Bacteroides disiens sp. nov. and Bacteroides bivius sp. nov. from human clinical infections. International Journal of Systematic Bacteriology 27: $337-345$.

Laemmli U K 1970 Cleavage of structural proteins during the assembly of the head of bacteriophage T4. Nature 227:680 685.

Lowry O H, Rosebrough N J, Farr A L, Randall R J 1951 Protein measurement with the folin-phenol reagent. Journal of Biological Chemistry 193: 265-275.

Moore W E C, Hash D E, Holdeman L V, Cato E P 1980 Polyacrylamide slab gel electrophoresis of soluble proteins for studies of bacterial floras. Applied and Environmental Microbiology 39: 900-907.

Poxton I R, Brown R 1979 Sodium dodecyl sulphate-polyacrylamide gel electrophoresis of cell-surface proteins as an aid to the identification of the Bacteroides fragilis group. Journal of General Microbiology 112: 211-217.

Poxton I R, Brown R 1986 Immunochemistry of the surface carbohydrate antigens of Bacteroides fragilis and definition of a common antigen. Journal of General Microbiology 132: 2475-2481.

Poxton I R, Sutherland I W 1976 The butanol-soluble proteins of Klebsiella aerogenes. Microbios 15: 93-103.

Poxton I R, Brown R, Collee J G 1982 Detection of speciesspecific and cross-reactive cell-surface antigens of Bacteroides species by an indirect enzyme-linked immunosorbent assay. Journal of Medical Microbiology 15 : 223-231.

Towbin H, Staehelin T, Gordon J 1979 Electrophoretic transfer of proteins from polyacrylamide gels to nitrocellulose sheets: procedure and some applications. Proceedings of the National Academy of Sciences of the USA 76:4350-4354.

Tsai C M, Frasch C E 1982 A sensitive silver stain for detecting lipopolysaccharides in polyacrylamide gels. Analytical Biochemistry 119 : 115-119. 